\title{
Perancangan E-Resource Perpustakaan Menggunakan Customer Relationship Management Berbasis Mobile
}

\author{
Putri Taqwa Prasetyaningrum ${ }^{1}$, Ozzi Suria $^{2}$, Arita Witanti ${ }^{3}$ \\ Sistem Informasi, Universitas Mercu Buana Yogyakarta \\ Jl. Jembatan Merah No. 84C Yogyakarta, Telp. 0274-584922 \\ e-mail: 12putri@mercubuana-yogya.ac.id, 20zzisuria@mercubuana-yogya.ac.id, \\ 3arita@mercubuana-yogya.ac.id
}

\begin{abstract}
Abstrak
Perpustakaan adalah salah satu fasilitas yang membantu dalam penyediaan sumber daya dalam proses pendidikan, karena Perpustakaan menyediakan fasilitas pinjaman tanpa biaya. Perpustakaan dalam suatu Perguruan Tinggi memiliki peranan yang sangat penting bagi pembaca khususnya mahasiswa. Perpustakaan di Universitas Mercu Buana Yogyakarta memiliki minat baca cukup banyak. Hal ini dibuktikan melalui kuesioner yang dibagikan kepada 65 responden civitas akademik Mercu Buana Yogyakarta pada bulan Mei 2017, diperoleh hasil bahwa sebanyak 98.5\% responden membutuhkan aplikasi perpustakaan digital. Responden dalam penelitian ini adalah mahasiswa aktif Universitas Mercu Buana Yogyakarta. Oleh karena itu dibutuhkan suatu sistem yang memungkinkan anggota perpustakaan untuk mengakses layanan perpustakaan secara online menggunakan aplikasi mobile berbasis iOS/Android. Hasil penelitian ini adalah perancangan e-Resource berbasis mobile untuk membaca dan menyimpan ebook yang dipinjam, transaksi meminjam tanpa biaya, akses repository tesis/skripsi, akses ke jurnal universitas, akses jurnal internasional, dan pembaharuan referensi yang cepat. Aplikasi IOS/Android perpustakaan juga akan menyediakan fasilitas untuk membantu pencarian buku yang dilakukan oleh anggota Perpustakaan dengan pilihan pencarian seperti judul, penulis, penerbit atau jenis buku. Pengembangan perangkat lunak yang di lakukan pada penelitian ini menggunakan metode Waterfall. Berbasis manajemen hubungan Customer Relationship Management (CRM) sebagai salah satu strategi peningkatan pelayanan yang berorientasi pada kebutuhan anggota. Salah satu karakteristik yang ingin ditonjolkan dari CRM adalah adanya interaksi antara penyedia layanan dan anggotanya. Dari interaksi tersebut, pihak penyedia layanan dapat menggali kebutuhan-kebutuhan para anggotanya untuk segera ditindaklanjuti. CRM mewakili kombinasi layanan teknologi dan informasi dengan tujuan untuk membangun sebuah sistem.
\end{abstract}

Kata kunci: Perpustakaan, e-Resource, Customer Relationship Management (CRM), Mobile/IOS.

\begin{abstract}
A library is one of the facilities that assist in providing resources for the educational process because the library provides book-lending facilities at no cost. The existence of a library in a college has a very important role for readers, especially students. The library of Universitas Mercu Buana Yogyakarta has a considerable reading interest. This is proven through a questionnaire distributed to 65 respondents of the academicians of Universitas Mercu Buana Yogyakarta in May 2017. It was found that 98.5\% of respondents need a digital library application. Respondents in this study were active students of Universitas Mercu Buana. Therefore, the system used to access online services was the iOS / Android mobile application. The result of this study is a design of mobile/IOS-based e-resource to read and store the borrowed e-books, borrowing transactions without fees, thesis repository access, access to university journals, access to international journals, and quick reference updates. The IOS/Android library application will also provide facilities to help library members to find books with various searching options such as title, author, publisher or book type. The software development carried out in this study uses the Waterfall method. Based on Customer Relationship Management (CRM) as one of the service improvement strategy, this system is oriented to the needs of members. One of the characteristics that will be featured from CRM is the interaction between the service provider and its members. From these interactions, service providers can explore the needs of its members to be followed up immediately. CRM represents a combination of technology and information services with the aim of building a system.
\end{abstract}

Keywords: Library, e-Resources, Customer Relationship Management (CRM), Mobile/IOS. 


\section{Pendahuluan}

Perpustakaan Sebagai salah satu bagian yang penting di perguruan tinggi, Perpustakaan membutuhkan sistem informasi yang akurat dan cepat. Perpustakaan adalah alat sumber pengetahuan dari berbagai disiplin ilmu. Perpustakaan biasanya diaktifkan oleh pengunjung sebagai media untuk mencari referensi dan memperoleh informasi. Perpustakaan adalah salah satu fasilitas yang membantu dalam penyediaan sumber daya dalam proses pendidikan, karena Perpustakaan menyediakan fasilitas pinjaman tanpa biaya [1].

Berdasarkan hasil dari kuesioner yang dibagikan kepada 65 responden civitas akademik Universitas Mercu Buana Yogyakarta pada bulan Mei 2017, diperoleh hasil bahwa sebanyak 98.5\% responden membutuhkan aplikasi perpustakaan digital. Responden sebagian besar berasal dari mahasiswa aktif Universitas Mercu Buana Yogyakarta dengan jumlah 92.3\%. Melalui kuesioner responden juga memberikan masukan untuk fitur aplikasi perpustakaan digital seperti adanya Personal Library untuk membaca dan menyimpan e-book yang dipinjam, transaksi meminjam tanpa biaya, akses repository tesis/skripsi, akses ke jurnal universitas, akses jurnal internasional, dan pembaharuan referensi yang cepat.

Perpustakaan digital juga diperlukan untuk meningkatkan minat membaca. Melalui hasil kuesioner, dari $100 \%$ responden yang ingin menggunakan aplikasi perpustakaan digital, hanya $63,1 \%$ responden yang sering berkunjung ke perpustakaan secara langsung. Selain itu, responden yang sering meminjam buku dari perpustakaan hanya 53,8\%. Hal ini menunjukkan bahwa perlu adanya suatu sistem yang mendukung pelayanan perpustakaan untuk meningkatkan minat dan kebiasaan membaca pengunjung.

Untuk mempercepat proses layanan pencarian dan peminjaman buku ke perpustakaan, dibutuhkan suatu sistem yang memungkinkan anggota perpustakaan untuk mengakses layanan perpustakaan secara online menggunakan aplikasi mobile berbasis iOS/Android. Aplikasi ini juga akan menyediakan fasilitas untuk membantu pencarian buku yang dilakukan oleh anggota Perpustakaan dengan pilihan pencarian seperti judul, penulis, penerbit atau jenis buku.

Aplikasi akan dirancang dengan menggunakan Customer Relationship Management (CRM) yang berbasis mobile. Hasil dari perancangan ini diharapkan dapat memenuhi meningkatkan kualitas akses dan konten informasi terutama hasil-hasil riset ilmiah dan meningkatkan perilaku pengunjung perpustakaan untuk lebih aktif dalam melakukan pencarian informasi perpustakaan dengan memanfaatkan sumbersumber informasi dalam bentuk elektronik dan dengan adanya CRM terdapat interaksi antara penyedia layanan dan anggotanya. Dari interaksi tersebut, pihak penyedia layanan dapat menggali kebutuhankebutuhan para anggotanya untuk segera ditindaklanjuti. CRM di sini mewakili kombinasi layanan teknologi dan informasi dengan tujuan untuk membangun sebuah sistem.

\section{Metodologi Penelitian}

\subsection{Teknik Pengumpulan Data}

Data pada penelitian ini dikumpulkan dengan menggunakan beberapa metode antara lain:

1. Studi Kepustakaan

Studi kepustakaan dilakukan dengan mencari sumber-sumber pustaka yang mendukung penelitian dan memberikan informasi yang memadai dalam menyelesaikan penelitian ini. Studi kepustakaan yang digunakan antara lain: buku, jurnal, artikel dan paper.

2. Observasi

Observasi dilakukan dengan pengamatan langsung terhadap objek yang akan diteliti terkait permasalahan yang akan dibahas, yaitu dengan mengunjungi Perpustakaan Universitas Mercu Buana Yogyakarta untuk melihat dan mengamati kegiatan yang terjadi antara perusahaan tersebut.

3. Wawancara

Melakukan tanya jawab secara lisan dengan pihak-pihak terkait obyek penelitian untuk mendapatkan informasi dan memperoleh data-data yang rinci yang nantinya digunakan untuk membangun sistem yang akan dibangun.

4. Kuesioner

Merupakan daftar pertanyaan yang diberikan kepada orang lain bersedia memberikan respons (responden) sesuai dengan permintaan pengguna. Tujuan ialah mencari informasi yang lengkap mengenai suatu masalah dan responden tanpa merasa khawatir bila responden memberikan jawaban yang tidak sesuai dengan kenyataan dalam pengisian daftar pertanyaan.

\subsection{Metode Pengembangan Perangkat Lunak}

Dalam Pengembangan Perangkat Lunak dalam penelitian ini digunakan model waterfall karena dikerjakan langkah per langkah seperti air mengalir. 
1. Analisis Strategi Bisnis

Analisis strategi bisnis ini dilakukan untuk melakukan verifikasi kebutuhan CRM.

2. Pemilihan Permodelan CRM

Pemilihan permodelan CRM dilakukan sesuai dengan hasil kuesioner untuk menentukan fitur yang dibutuhkan pada E-Resource yang mengacu pada model CRM

3. Analisis kebutuhan perangkat lunak

Analisis kebutuhan perangkat lunak dilakukan untuk menggali kebutuhan perangkat lunak yang akan dibangun.

4. Perancangan perangkat lunak

Perancangan perangkat lunak dilakukan untuk merancang perangkat lunak yang akan dibangun sehingga dapat diperoleh gambaran detail system.

Bagan alur (flowchart) metode penelitian ini dapat diilustrasikan pada Gambar 1 berikut.

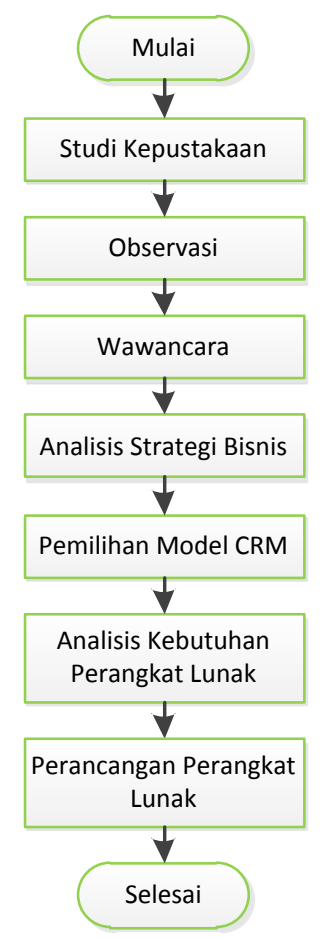

Gambar 1. Flowchart perencanaan aplikasi.

\subsection{Definisi E-Resources dan Perpustakaan Digital}

E-resources dalam definisi di atas menunjuk pada semua bahan (koleksi) yang membutuhkan akses komputer baik secara remote (jarak jauh) maupun secara local melalui komputer personal (PC), mainframe, atau perangkat mobile. Hal ini menunjukkan bahwa setiap sumber informasi atau sumber daya informasi yang aksesnya melalui perangkat komputer, maka dapat dinamakan sebagai sumber daya elektronik atau e-resources [2].

Sedangkan perpustakaan digital atau digital libraries dapat dipahami sebagai suatu sistem yang mengakomodasi fungsi perpustakaan 'tradisional' dalam lingkungan 'digital' atau 'elektronik'. Hal ini diperkuat dengan definisi yang dirangkum oleh Cleveland (1998), yaitu:

"Digital libraries are the digital face of traditional libraries that include both digital collections and traditional, fixed media collections. So they encompass both electronic and paper materials." dan/atau;

"Digital libraries will serve particular communities or constituencies, as traditional libraries do now, though those communities may be widely dispersed throughout the network".

Kedua definisi di atas menegaskan bahwa elemen sumber daya elektronik merupakan satu bagian dari elemen yang mendukung perpustakaan digital yang fungsinya bisa jadi merupakan cerminan yang sekarang ada dalam perpustakaan tradisional. Pada tulisan ini kita akan memfokuskan pada perpustakaan digital dalam kerangka sumber daya elektronik atau e-resources [3]. 


\subsection{Enterprise Sistem Informasi}

Enterprise adalah sebuah sistem dari manusia, peralatan, material, data, kebijakan dan prosedur yang muncul untuk menyediakan sebuah produk atau pelayanan dengan tujuan mendapatkan keuntungan. Sistem enterprise mendukung struktur organisasi yang sebelumnya tidak mungkin untuk menciptakan budaya organisasi yang lebih disiplin. Sistem Informasi adalah pengaturan orang, data, proses dan teknologi informasi (IT) yang berinteraksi untuk mengumpulkan, memproses, menyimpan, dan menyediakan sebagai otuput informasi yang diperlukan untuk mendukung sebuah organisasi(Whitten L, 2004).Sistem Informasi merupakan serangkaian komponen berupa manusia, prosedur, data, dan teknologi (seperti komputer) yang digunakan untuk melakukan sebuah proses untuk menghasilkan informasi yang bernilai untuk pengambilan keputusan [4]. Enterprise Sistem informasi menyediakan platform teknologi yang dapat mengorganisir untuk mengintegrasikan dan mengkoordinasi dengan proses bisnis yang ada [5]. Sistem Informasi berskala enterprise mengintegrasikan bermacam fungsionalitas yang ada dalam sebuah perusahaan/enterprise contohnya dapat terintegrasi dengan CRM.

\subsection{Customer Relationship Management (CRM)}

CRM merupakan suatu strategi bisnis yang menggunakan teknologi informasi untuk menyediakan pandangan yang dalam, tepat dan terintegrasi mengenai pelanggannya, sehingga semua proses dan interaksi dengan pelanggan dapat menghasilkan keuntungan [6].

Arsitektur CRM adalah mengorganisasikan proses CRM di sekitar pelanggan dan bukan pada proses internal di dalam proses fungsional seperti pemasaran dan penjualan. Dengan kata lain, tindakan yang dilakukan perusahaan tidak diprioritaskan pada unit fungsional perusahaan melainkan diprioritaskan pada tujuan perusahaan secara keseluruhan untuk menciptakan kepuasan pelanggan. Proses yang harus dilakukan sebelumnya adalah melakukan restrukturisasi pada proses interaksi dengan pelanggan, karena struktur fungsional dan organisasional perusahaan cenderung memisahkan aktivitas yang dilakukan dalam memberikan pelayanan pelanggan, sehingga mencegah penyebaran informasi yang berguna ke seluruh bagian perusahaan yang membutuhkan informasi tersebut karena informasi yang tidak dapat diberikan perusahaan ketika pelanggan membutuhkan akan menghalangi pembentukan hubungan yang dekat dan pribadi dengan pelanggan [7]. Dengan melihat kenyataan di atas, maka arsitektur sebuah CRM dapat digambarkan pada gambar berikut ini:

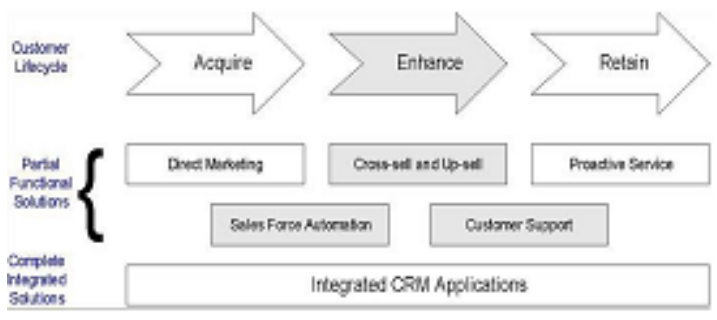

Gambar 2. CRM yang terintegrasi.

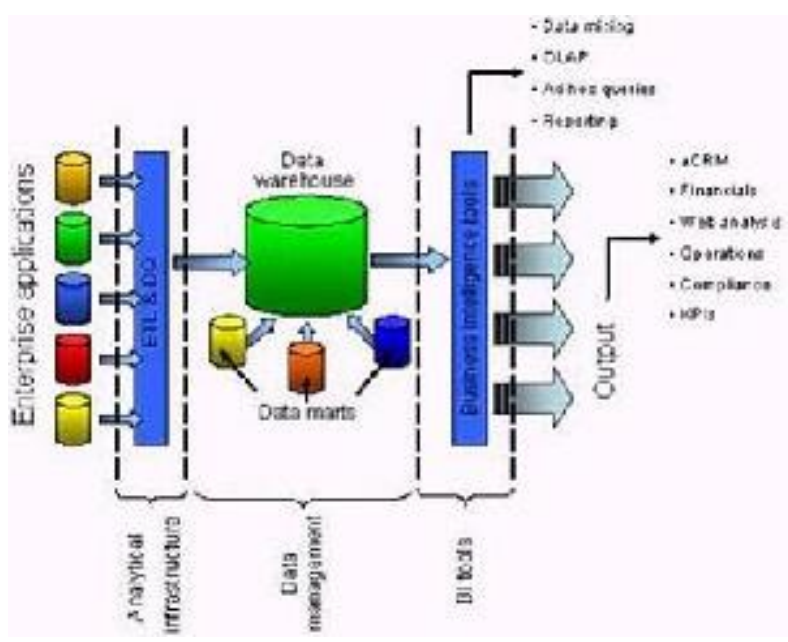

Gambar 3. CRM architecture (Sumber: Berson, 2000). 
Menurut pandangan Berson et al (2000) dalam arsitektur CRM sejumlah customer touch-point dan delivery channels yang menghasilkan dan menggunakan informasi dapat dilihat pada Gambar 2. Customer touch-point adalah points of contact dimana perusahaan dapat berinteraksi dan "touch" pelanggan dan begitu pula sebaliknya. Informasi ini perlu diintegrasikan dan dianalisis untuk mendapatkan sebuah gambaran yang lengkap dan akurat yang dapat menjadikannya menjadi pelanggan jangka panjang sebagai pelanggan produk atau jasa perusahaan [7] Gambar 3 merupakan arsitektur dari CRM.

\subsection{Model-model CRM}

Menurut Berson (2000) ada tiga aplikasi secara garis besar, yaitu operational CRM, analytical CRM dan collaborative CRM.

1. Operational CRM

Operational CRM adalah aplikasi-aplikasi yang berhubungan dengan proses bisnis (penjualan, pemasaran, pelayanan) termasuk di dalamnya customer touchpoints dan customer channels dan integrasi front office-back office.

2. Analytical CRM

Aplikasi CRM yang memungkinkan perusahaan untuk mendapatkan suatu pengetahuan akan pelanggan dan melakukan analisa, penaksiran atau estimasi terhadap pelanggan berdasarkan data-data analisis yang dipakai. Pengetahuan yang didapat adalah tentang nilai pelanggan, yang dapat mendukung channel pelayanan interaksi dengan baik dan mendukung berbagai keputusan dalam menyinergi penerapan operational dan/atau collaborative CRM dalam proses penjualan dan pemasaran produk, sehingga kedudukannya menjadi sangat esensial bagi komponen CRM lainnya.

3. Collaborative CRM

Seperangkat aplikasi dari pelayanan kolaborasi termasuk e-mail, ecommunities, forum diskusi dan alat lainnya yang sejenis dirancang untuk melintasi interaksi antara para pelanggan dengan perusahaan. Dengan collaborative CRM perusahaan berkolaborasi dengan partner, pemasok dan pelanggan untuk memperbaiki proses dan memperbaiki kebutuhan pelanggan. Manfaat penggunaan CRM berbasis web-site adalah untuk membantu perusahaan dalam menyebarkan informasi serta melakukan interaksi dengan pelanggan dari berbagai tempat [7].

\subsection{Mobile Perpustakaan}

Penelitian di China tahun 2010 menunjukkan ketika jumlah pemustaka sebagian besar memiliki handphone maka mobile library ini menjadi solusi efektif tersebarnya sumber bacaan dari perpustakaan. Mobile library ini mengurangi budget, staf dan mampu memberikan jangkauan yang luas [8].

Studi terdahulu tentang mobile perpustakaan bahwa melalui android smartphone sebagai perangkat mobile, anggota perpustakaan dapat melakukan pencarian informasi koleksi perpustakaan, selain itu juga dapat membantu peminjaman buku secara online dan memonitor status peminjaman buku untuk menghindari delay pengembalian buku. Mobile perpustakaan dalam penelitian ini masih sebagai supporting system, pemustaka harus datang sendiri ke perpustakaan jika akan meminjam buku [9].

Riset sebelumnya telah mempelajari pengembangan elektronik library dengan mobile device pada android platform, mulai dari perancangan sampai implementasi menggunakan Eclipse. Namun prosesnya masih pada add, update, delete serta approving penambahan material library [10].

Pada riset ini selain perpustakaan dalam bentuk e-resource, proses pinjam meminjam juga dilakukan secara online dan dibaca melalui reader yang disediakan dengan menggunakan Customer Relationship Management (CRM). Adanya CRM terdapat interaksi antara penyedia layanan dan anggotanya.

\section{Hasil dan Analisis}

Pada sub berikut ini akan membahas tentang analisis kebutuhan sistem yang dilakukan, antara lain: analisis kebutuhan sistem, class diagram, entity relationship diagram, arsitektur perangkat lunak, perancangan perangkat lunak yang telah dikembangkan.

\subsection{Analisis Kebutuhan Sistem}

Berdasarkan permasalahan yang terjadi, peneliti menemukan requirement pengembangan aplikasi ini seperti yang dinyatakan pada Gambar 4 . 

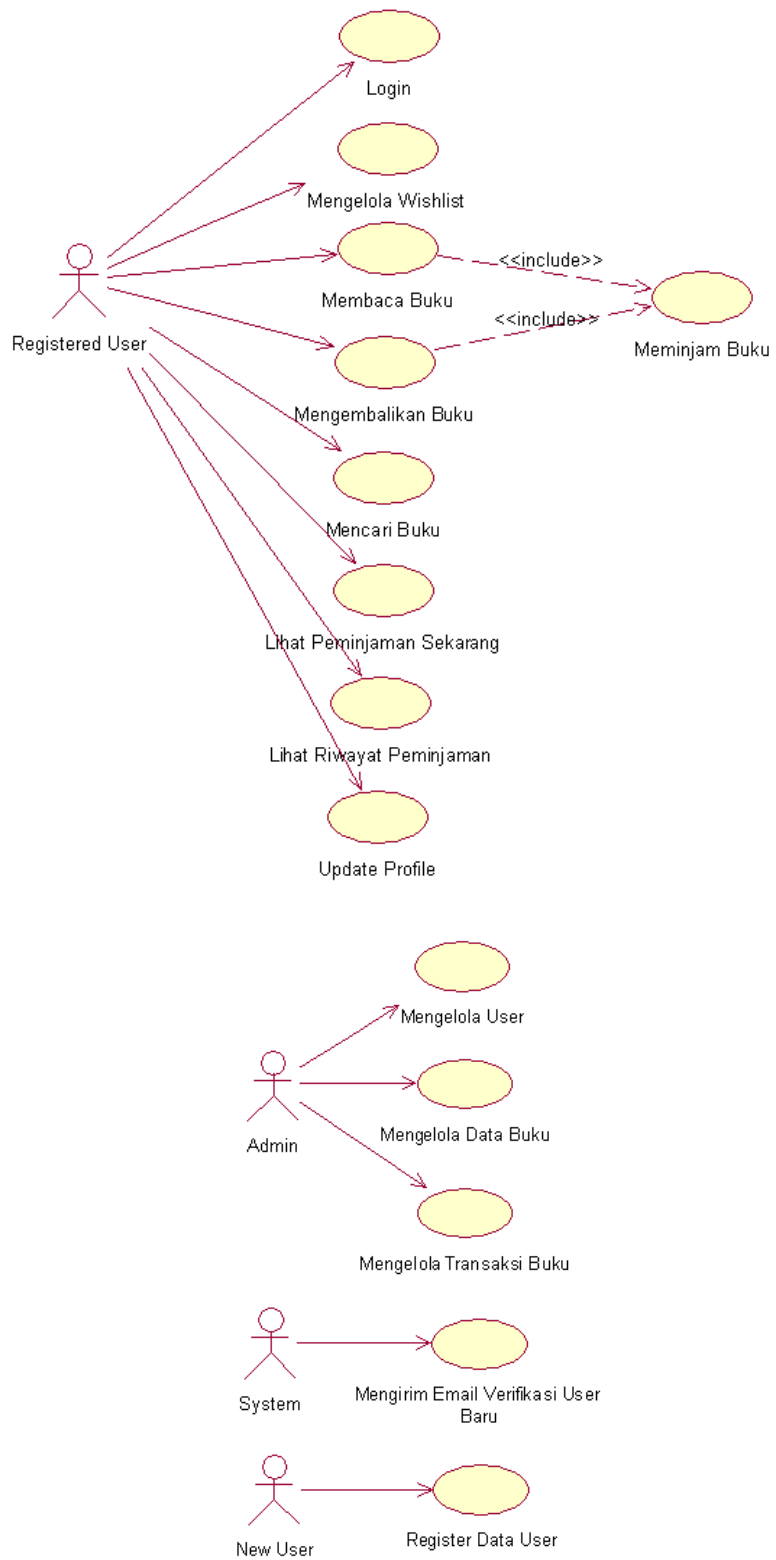

Gambar 4. Use case diagram.

Pada Gambar 4, ada 4 aktor yang akan berinteraksi dengan sistem, yaitu Registered User, Admin, System, dan New User.

\subsection{Class Diagram}

Perancangan untuk kebutuhan pengembangan sistem ditampilkan pada Class Diagram di Gambar 5. Class Diagram menampilkan kelas-kelas perancangan yang nantinya akan digunakan sebagai dasar untuk melakukan pengkodean sistem. Terdapat 3 kelas yang ditampilkan pada Class Diagram, yaitu Entity (model), Boundary (view), dan Control (controller). Kelas Entity mendeskripsikan informasi data utama yang terdiri dari atribut data dan operasi yang digunakan untuk menyimpan data secara persistent. Kelas Boundary mendeskripsikan operasi yang dapat dilakukan dari tampilan yang ditampilkan kepada pengguna serta atribut data yang digunakan sebagai input dari pengguna. Kelas Control digunakan untuk menghubungkan antara kelas Boundary dan kelas Entity. Pada umumnya kelas Control berisi operasi yang digunakan untuk memproses input-an data dari pengguna melalui kelas Boundary. Output dari kelas 
Control dapat ditujukan ke kelas Entity untuk disimpan dan juga dikembalikan ke kelas Boundary untuk ditampilkan kepada pengguna.

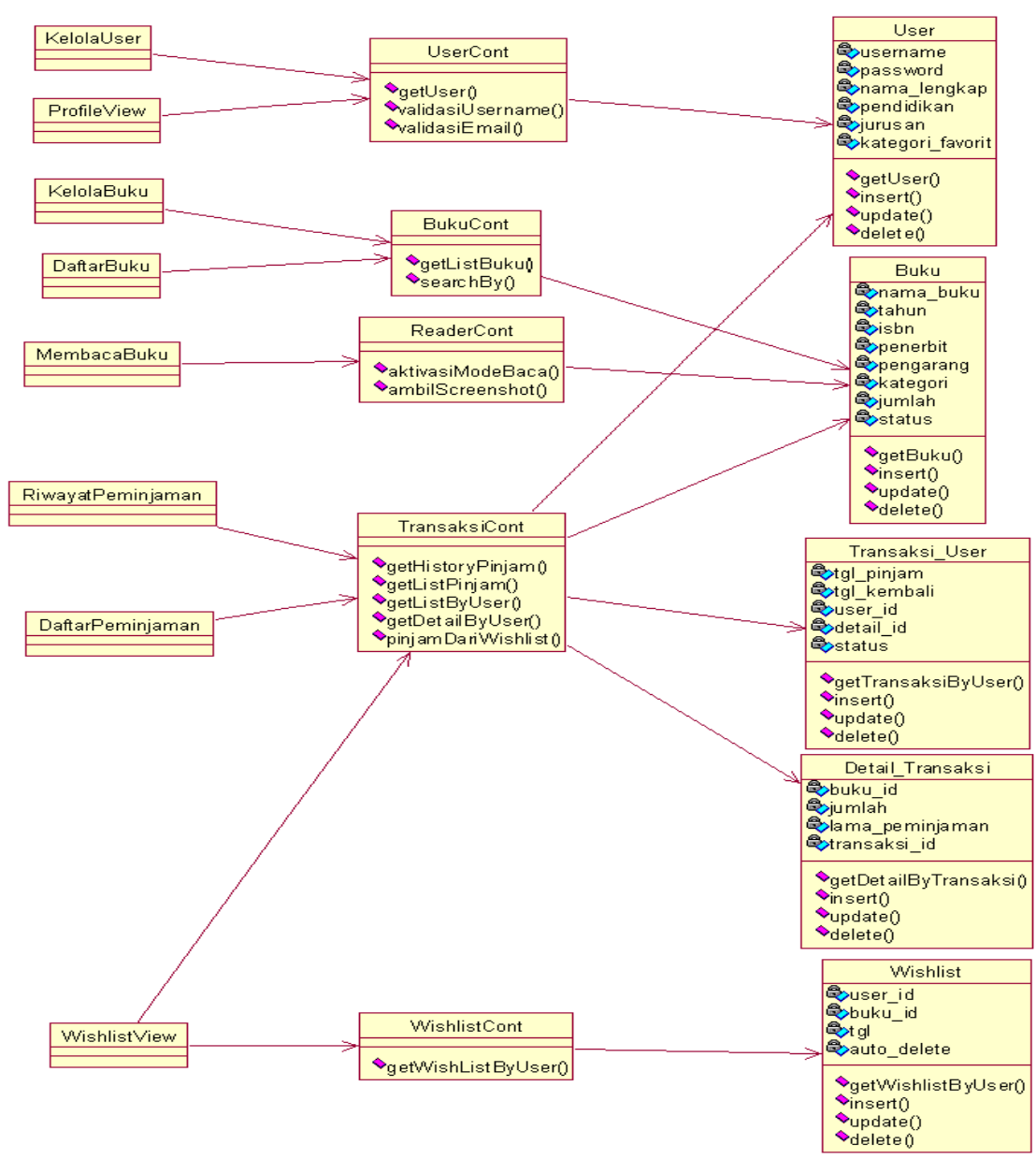

Gambar 5. Class diagram.

\subsection{Entity Relationship Diagram}

Entity Relationship Diagram (ERD)merupakan diagram yang digunakan untuk menggambarkan hubungan antara entitas-entitas yang ada dalam suatu sistem informasi. Berikut adalah gambaran dari ERD dari Perancangan E-Resource Perpustakaan Menggunakan Customer Relationship Management. 


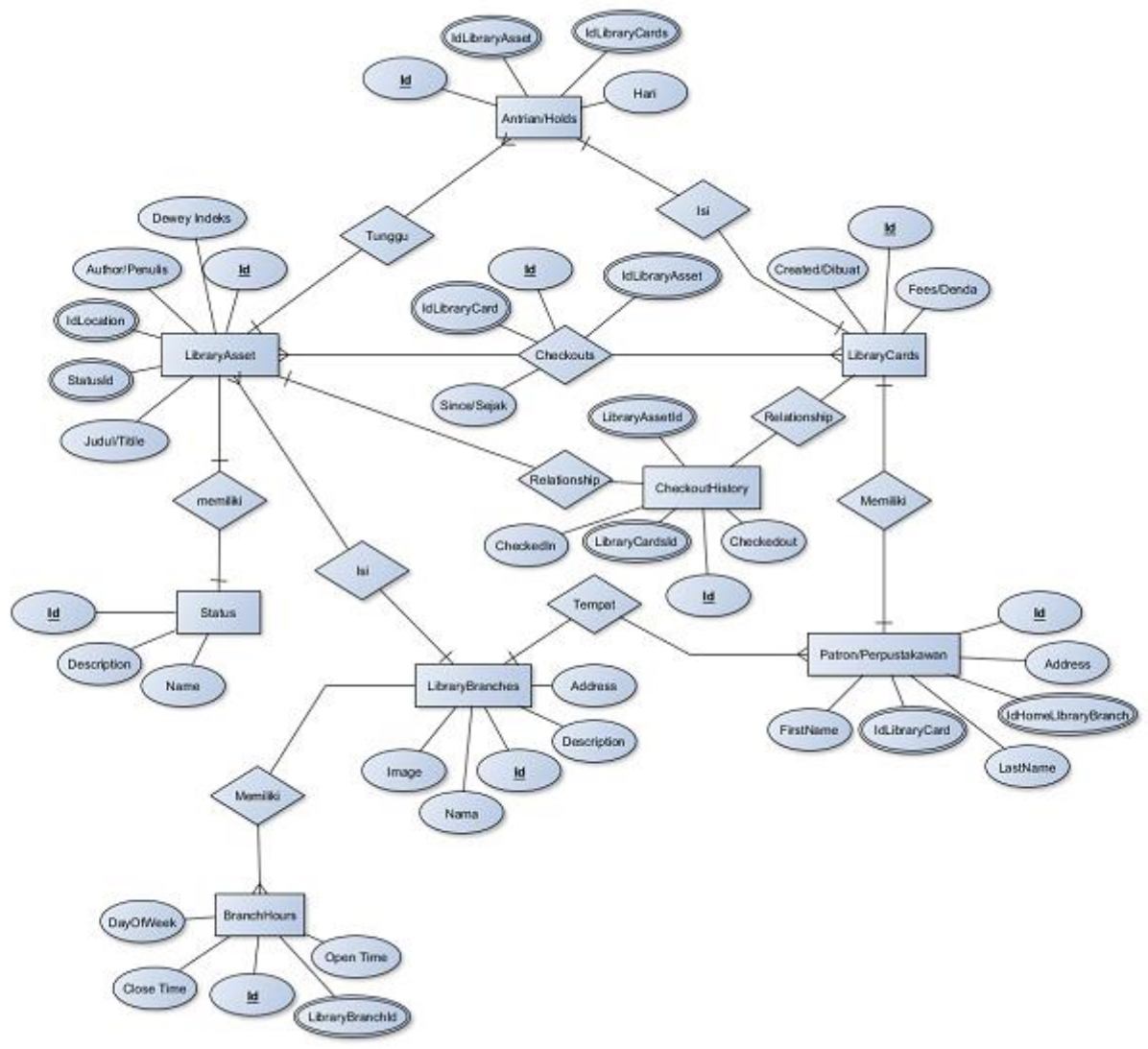

Gambar 6. Entity Relationship Diagram.

\subsection{Arsitektur Perangkat Lunak}

Berdasarkan analisis yang dilakukan terhadap permasalahan dengan menggunakan langkahlangkah pada metode pengembangan perangkat lunak yaitu pada fase desain, maka dapat diperoleh gambaran mengenai arsitektur perangkat lunak E-Resource Perpustakaan dengan CRM yang akan dibuat, seperti yang dinyatakan pada Gambar 7.

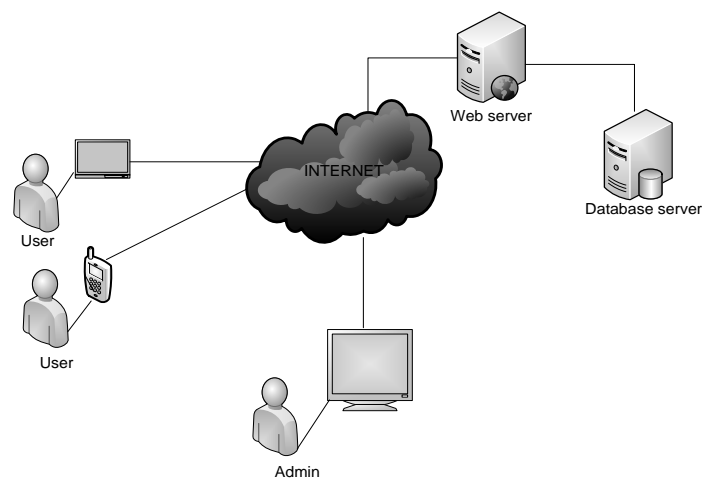

Gambar 7. Arsitektur perangkat lunak e-resource perpustakaan dengan CRM.

\section{Implementasi}

Aplikasi ini digunakan membantu Perpustakaan dalam mempercepat proses layanan pencarian dan peminjaman buku ke perpustakaan, dibutuhkan suatu sistem yang memungkinkan anggota perpustakaan untuk mengakses layanan perpustakaan secara online menggunakan aplikasi mobile berbasis iOS/Android. Aplikasi ini juga akan menyediakan fasilitas untuk membantu pencarian buku yang dilakukan oleh anggota Perpustakaan dengan pilihan pencarian seperti judul, penulis, penerbit atau jenis buku. 
Tujuan Penelitian ini diharapkan dapat menghasilkan sebuah prototype yang dirancang dengan menggunakan Customer Relationship Management (CRM) yang berbasis mobile iOS/Android. Halaman Dashboard admin merupakan halaman utama sistem dimana terdapat petunjuk penggunaan sistem dan juga tab-tab untuk melakukan manajemen data-data pariwisata. Tampilan halaman dashboard pada Gambar 9.

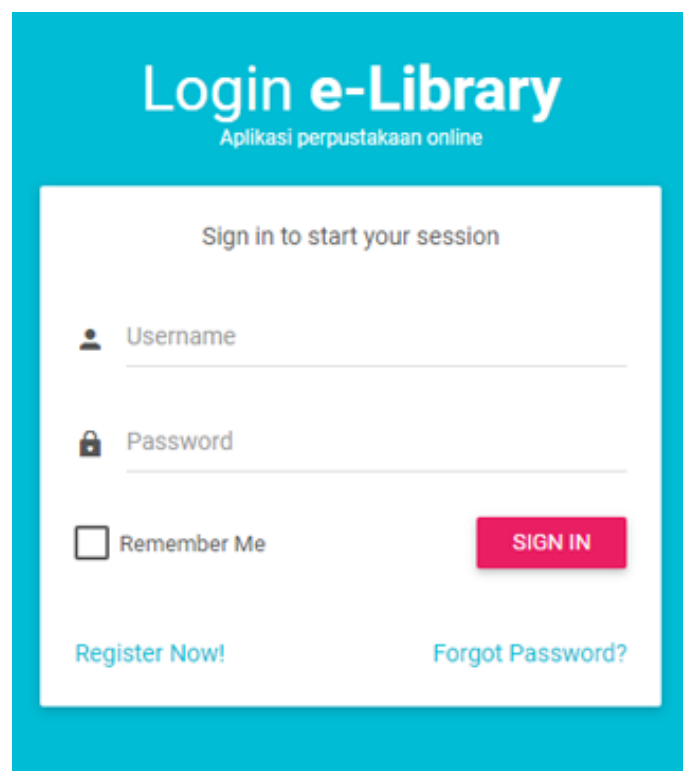

Gambar 8. Halaman login.

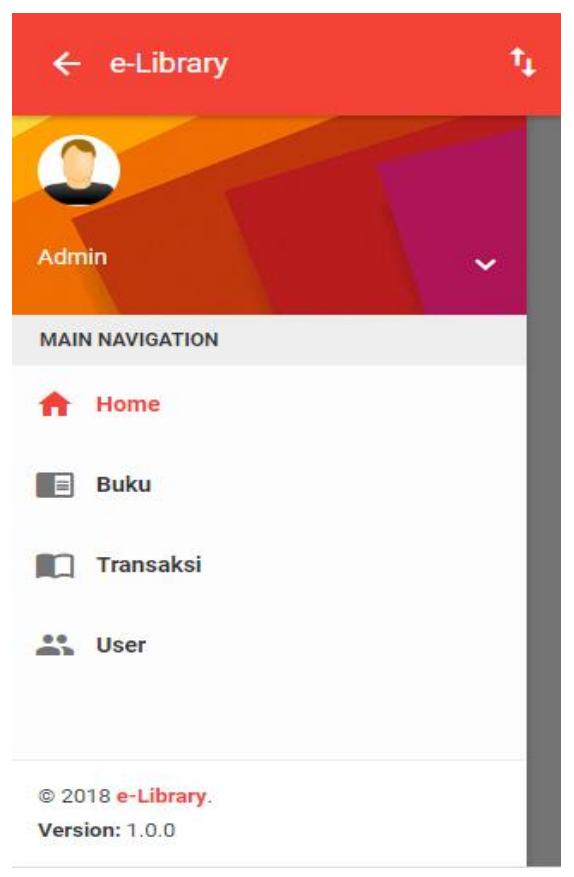

Gambar 9. Dashboard admin. 


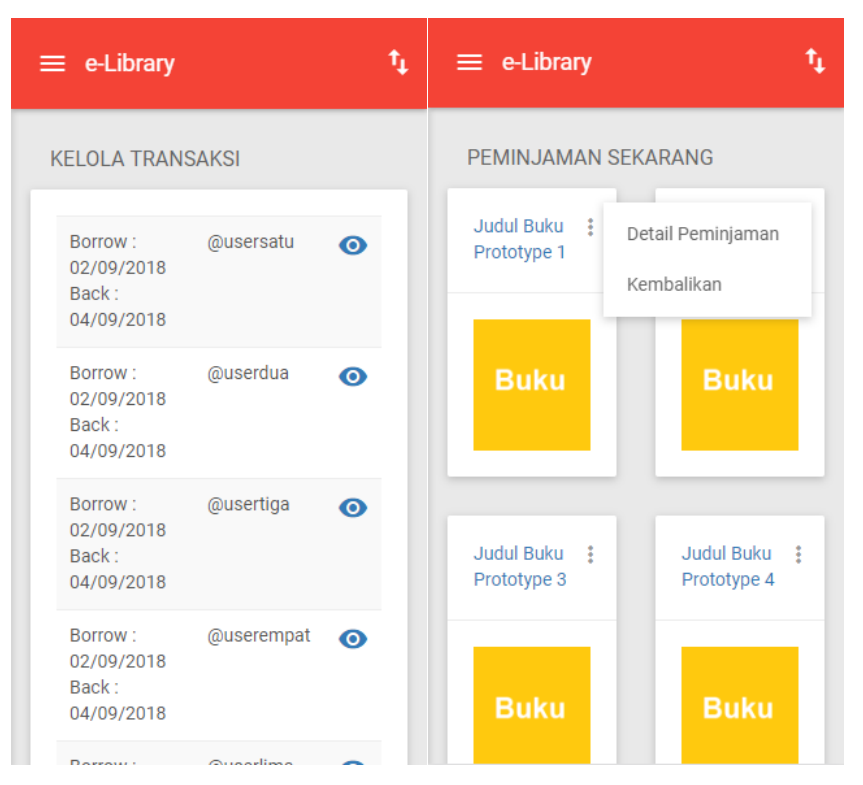

Gambar 10. Transaksi peminjaman.

\section{Simpulan}

Berdasarkan dari hasil analisis ditemukan rumusan masalah yang kemudian dibuat suatu prototype solusi berjudul: Perancangan E-Resource Perpustakaan Menggunakan Customer Relationship Management Berbasis Mobile, Proses pendaftaran dan peminjaman dapat dilakukan setiap saat secara on-line, dan kartu anggota dapat langsung dicetak kapan saja oleh administrator dari sistem e-library. Fitur-fitur yang ada dibuat untuk menjembatani komunikasi antara anggota, kepala perpustakaan dan pengelola perpustakaan dan meningkatkan perilaku pengunjung perpustakaan untuk lebih aktif dalam melakukan pencarian informasi perpustakaan dengan memanfaatkan sumber-sumber informasi dalam bentuk elektronik dan dengan adanya CRM terdapat interaksi antara penyedia layanan dan anggotanya.

\section{Daftar Pustaka}

[1] Hendriana, Y. (2015). Development of Mobile Library Application Based on Android in Universitas Ahmad Dahlan, 1064-1071. https://doi.org/10.15680/IJIRSET.2015.0403055.

[2] Ladjamudin, Analisa dan Desain Sistem Informasi, Yogyakarta: Graha Ilmu, 2008.

[3] Surachman, A. (2012). Pengembangan E-Resources: salah satu upaya membangun perpustakaan digital $1,1-14$.

[4] Cleveland, Gary. (2008). Digital Libraries: Definitions, Issues and Challenges. Occasional Paper 8. Ottawa: Universal Dataflow and Telecommunications Core Programme, International Federation of Library Associations and Institutions (IFLA). Tersedia di http://www.ifla.org/udt/op/ diakses tanggal 5 Januari 2018.

[5] E. Suherman, Desain Pembelajaran Kewirausahaan, Bandung: Alfabeta, 2008.

[6] L. Efraim Turban, Information Technology for Management, 2012: International Student Version..

[7] Berson, A., Smiith, S., \& Thearling, K. (2000). Building Data Mining Applications for CRM. McGraw-Hill, New York.

[8] Huang,C, " Mobile Services in University Libraries in China," in IEEE, 3563-3565., 2011.

[9] Y. Hendriana, "Development of Mobile Library Application Based on Android in Universitas Ahmad Dahlan," International Journal of Innovative Research in Science, vol. Vol. 4, no. Issue 3, pp. 10641071, 2015.

[10] Aliyal, K., \& Samae, T. (2015). The paper considers mobile peculiarities of the development for Android platform by the example of an electronic library. Here by we concentrate on applications development on the example of Eclipse development environment., (Iccas), 1682-1686. 